Retraction

\title{
Retracted: DFT Based QSAR Study of Enzyme Ribonucleoside Diphosphate Reductase
}

\section{Journal of Chemistry}

Received 19 September 2020; Accepted 19 September 2020; Published 1 December 2020

Copyright (c) 2020 Journal of Chemistry. This is an open access article distributed under the Creative Commons Attribution License, which permits unrestricted use, distribution, and reproduction in any medium, provided the original work is properly cited.

Journal of Chemistry has retracted the article titled "DFT Based QSAR Study of Enzyme Ribonucleoside Diphosphate Reductase" [1], as it is essentially identical in technical content with a previously published paper titled "QSAR Study on Inhibitors of Enzyme Ribonucleoside Diphosphate Reductase," by Ved Prakash Singh, Durga Nath Dhar, and Ravi Kumar Srivatsava in Asian Journal of Chemistry, Volume 21, Issue 10, pp. 2052-2058, 2009 [2].

\section{References}

[1] M. Ansari, R. K. Ahmad Khalid, and S. A. Khan, "DFT Based QSAR Study of Enzyme Ribonucleoside Diphosphate Reductase," Journal of Chemistry, vol. 7, Article ID 254539, 9 pages, 2010.

[2] V. P. Singh, D. Durga Nath, and R. Kumar Srivatsava, "QSAR Study on Inhibitors of Enzyme Ribonucleoside Diphosphate Reductase," Journal of Chemistry, vol. 21, no. 10, pp. 20522058, 2009. 